\title{
Evaluation of Intracerebral Hemorrhage Functional Outcome Score informativeness for identification of short-term vital outcome in patients with spontaneous supratentorial intracerebral haemorrhage
}

\author{
A. A. Kuznietsov \\ Zaporizhzhia State Medical University, Ukraine
}

Key words:

cerebral

hemorrhage,

X-Ray tomography,

mortality,

prognosis.

Zaporozhye

medical journal

2018; 20 (6), 752-756

Dol:

10.14739/2310-1210

2018.6.146536

E-mail:

titus3.05@gmail.com
The main purpose of the study was to conduct the informative value of Intracerebral Hemorrhage Functional Outcome Score (ICH-FOS) assessment for the determination of a short-term vital prognosis in patients with spontaneous supratentorial intracerebral hemorrhage (SSICH)

Materials and methods. A prospective, cohort study was conducted among 191 patients (117 men and 74 women, the mean age was $65.1 \pm 0.8$ years) with SSICH treated in a conservative manner. This study included clinical assessment (National Institute of Health Stroke Scale, Glasgow Coma Scale), neuroimaging and biochemistry examination. The ICH-FOS was used in order to conduct a complex assessment of the patients' state severity on admission. The functional outcome of the SSICH acute period was assessed on the 21 st day of the disease in accordance with the modified Rankin Scale.

Results. Lethal outcome was noted in 22 patients $(11.5 \%)$. The patients with the lethal outcome during the acute period had a higher value of the ICH-FOS (8 (7-10) versus $4(3-6), \mathrm{P}<0.0001)$ in the onset of SSICH. Based on a ROC-analysis it was determined that the ICH-FOS $>6$ is the predictor of the lethal outcome in the acute period of SSICH ( $\mathrm{Se}=77.3 \%$; Sp $=81.1 \%$; AUC $\pm \mathrm{SE}$ $(95 \% \mathrm{Cl})=0.86 \pm 0.04(0.80-0.91), \mathrm{P}<0.0001)$. In the group of patients with the ICH-FOS value $>6(n=49)$ lethal outcome was noted in $34.7 \%$ of cases, whereas in the group of patients with the ICH-FOS value $\leq 6(n=142)$ it was noted only in $3.5 \%$ of cases.

Conclusions. The Intracerebral Hemorrhage Functional Outcome Score is a highly informative tool for the determination of a short-term vital prognosis of SSICH acute period outcome. The ICH-FOS $>6$ is associated with a 9.9-fold increased risk of lethal outcome (RR $95 \%$ Cl 3.8-25.3, P $<0.0001)$.
Киючові слова: внутрішньомозковий крововилив, комп'ютерна томографія, смертність, прогноз.

Запорізький медичний журнал. - 2018. T. 20, № 6(111). C. $752-756$

\section{Оцінювання інформативності Intracerebral Hemorrhage Functional Outcome Score} Аля визначення короткострокового вітального прогнозу в пацієнтів зі спонтанним супратенторіальним внутрішньомозковим крововияивом

\section{А. А. Кузнєцов}

Мета роботи - оцінити інформативність Intracerebral Hemorrhage Functional Outcome Score (ICH-FOS) для визначення короткострокового вітального прогнозу в пацієнтів зі спонтанним супратенторіальним внутрішньомозковим крововиливом (ССВМК).

Матеріали та методи. Здійснили проспективне, когортне дослідження 191 пацієнта (117 чоловіків і 74 жінки, середній вік $-65,1 \pm 0,8$ року) зі ССВМК, які отримували консервативну терапію. Дослідження включало оцінювання за клінічними шкалами (Шкала інсульту Національного інституту здоров'я США, Шкала коми Глазго), нейровізуалізаційне та біохімічне дослідження. Для комплексного оцінювання тяжкості стану пацієнтів під час надходження використовували ICH-FOS. Функціональні наслідки гострого періоду оцінювали на 21 добу захворювання за модифрікованою шкалою Ренкіна.

Результати. Летальний результат зафіксований у 22 пацієнтів (11,9\%). Пацієнти, в яких гострий період захворювання мав летальні наслідки, в дебюті CСВМК відрізнялися більшим значенням ICH-FOS (8 (7-10) проти 4 (3-6), p < 0,0001). На підставі ROC-аналізу встановлено, що ICH-FOS >6 є предиктором летального результату гострого періоду СCBMK (чутливість = 77,3\%; специфрічність = 81,1\%; AUC \pm SE $(95 \%$ Cl) = 0,86 $\pm 0,04(0,80-0,91), p<0,0001)$. У групі пацієнтів зі значенням ICH-FOS >6 ( $n=49)$ летальних випадків було $34,7 \%$, а в групі пацієнтів зі значенням ICH-FOS $\leq 6(n=142)-3,5 \%$.

Висновки. Intracerebral Hemorrhage Functional Outcome Score $€$ високоінформативним інструментом для визначення короткострокового вітального прогнозу наслідків гострого періоду SSICH (точність прогнозування = 90,6 \%). Intracerebral Hemorrhage Functional Outcome Score >6 асоційоване зі збільшенням ризику летального результату в 9,9 раза (RR $95 \% \mathrm{Cl} 3,8-25,3, \mathrm{p}<0,0001)$.

Ключевые слова: внутримозговое кровоизлияние, компьютерная томография, смертность, прогноз.

Запорожский медицинский

журнал. - 2018. -

T. 20, № 6(111). -

C. $752-756$
Оценка информативности Intracerebral Hemorrhage Functional Outcome Score Аля определения краткосрочного витального прогноза у пациентов со спонтанным супратенториальным внутримозговым кровоизлиянием

\section{А. А. Кузнецов}

Цель работы - оценить инфрормативность Intracerebral Hemorrhage Functional Outcome Score (ICH-FOS) для определения краткосрочного витального прогноза у пациентов со спонтанным супратенториальным внутримозговым кровоизлиянием (ССВМК).

Материалы и методы. Проведено проспективное, когортное исследование 191 пациента (117 мужчин и 74 женщины, средний возраст 65,1 0,8 года) со ССВМК, которые получали консервативную терапию. Исследование включало оценку 
по клиническим шкалам (Шкала инсульта Национального института здоровья США, Шкала комы Глазго), нейровизуализационное и биохимическое обследования. Для комплексной оценки тяжести состояния пациентов при поступлении использовали ICH-FOS. Функциональный исход острого периода оценивали на 21 сутки заболевания по модифицированной шкале Рэнкина.

Результаты. Летальный исход зафиксирован у 22 пациентов (11,9 \%). Пациенты, у которых острый период заболевания имел летальный исход, в дебюте ССВМК отличались более высоким значением ICH-FOS (8 (7-10) против 4 (3-6), $\mathrm{p}<0,0001)$. На основании ROC-анализа установлено, что ICH-FOS >6 является предиктором летального исхода острого периода ССВМК (чувствительность $=77,3 \%$; специфичность $=81,1 \%$; AUC \pm SE $(95 \% \mathrm{Cl})=0,86 \pm 0,04(0,80-0,91)$, p < 0,0001). В группе пациентов со значением ICH-FOS >6 ( $n=49)$ летальный исход зарегистрирован в 34,7\% случаев, а в группе пациентов со значением ICH-FOS $\leq 6(n=142)$ - в $3,5 \%$.

Выводы. Intracerebral Hemorrhage Functional Outcome Score - высокоинформативный инструмент для определения краткосрочного витального прогноза исхода острого периода SSICH (точность прогнозирования = 90,6 \%). Intracerebral Hemorrhage Functional Outcome Score >6 ассоциировано с увеличением риска летального исхода в 9,9 раза (RR $95 \%$ $\mathrm{Cl} 3,8-25,3, \mathrm{p}<0,0001)$.

\section{Introduction}

Cerebral hemorrhagic stroke (CHS) and its most common form - spontaneous supratentorial intracerebral hemorrhage $(\mathrm{SSICH})$ occupies a leading position in the structure of adult mortality causes in most countries of the world $[1,4]$.

One of the ways to reduce the mortality caused by this pathology is to develop a differentiated approach for the determination of optimal tactics of patient management in the acute period of the disease. From this point of view, the verification of the short-term vital prognosis becomes especially significant, the latter being the basis for taking appropriate therapeutic and tactical decisions [3,5,12].

Modern neurological science has convincingly proved that the most effective tool for the prognosis verification is a complex assessment of the patient's state severity, including the use of appropriate scales [7,10]. Thus, the Intracerebral Hemorrhage Functional Outcome Score (ICH-FOS) takes into consideration a set of clinical, neurological and neuroimaging examinations and biochemical analysis results in the onset of CHS. Recent studies have proved the informative value of this scale in order to determine a long-term functional outcome in patients with $\mathrm{CHS}$ [8]

Any criteria for the verification of a short-term vital prognosis using the ICH-FOS for the assessment of patients with SSICH have not been developed. The latter has served as the basis for this study.

\section{The purpose}

The main purpose was to assess the informative value of the ICH-FOS for the determination of a short-term vital prognosis in patients with $\mathrm{SSICH}$.

\section{Materials and methods}

To achieve this goal a prospective, cohort, comparative study was conducted among 191 patients ( 117 men and 74 women, the mean age was $65.1 \pm 0.8$ years) in the acute period of spontaneous hemorrhage in the left (46.6\%) and the right brain hemispheres $(53.4 \%)$. The patients were hospitalized within the first 24 hours from the onset of the disease and underwent conservative therapy in the Brain Circulation Disorders Department of the Municipal Institution "City Clinical Hospital No 6" in accordance with the Unified Clinical Protocol for the provision of medical care to patients with cerebral hemorrhagic stroke, approved by the Order of the Ministry of Health of Ukraine No. 275 of April 17, 2014 [1].
The following criteria were the reasons for the exclusion from the study: 1) indications for surgical treatment in accordance with the results of examination by a neurosurgeon, 2) more than 1 lesion; 3) decompensated somatic pathology; 4) an autopsy-confirmed extracerebral cause of death.

The diagnosis was verified with reference to the neuroimaging study results, which was performed with the use of a multislice computed tomography scanner "Siemens Somatom Spirit" (Germany). The lesion size was determined using the following formula: intracerebral hemorrhage volume $(\mathrm{ICHV})=(\mathrm{a} \times \mathrm{b} \times \mathrm{c}) / 2$, where $\mathrm{a}, \mathrm{b}, \mathrm{c}$ are linear lesion sizes (cm). Presence or absence of secondary intraventricular hemorrhage (IVH) was also considered.

Clinical and neurological examination was performed on admission and in the course of the disease in accordance with the National Institute of Health Stroke Scale (NIHSS) and Glasgow Coma Scale (GCS). The functional outcome of the acute period of SSICH was assessed on the 21 st day of the disease in accordance with the modified Rankin Scale.

Blood glucose level as a part of biochemical analysis was measured at the biochemical laboratory at Municipal Institution "City Clinical Hospital No 6" in all patients on admission as standard of care.

The ICH-FOS was used in order to conduct a complex assessment of the patients' state severity on admission. It takes into consideration different grades of age, IHSS score, GCS score, ICH volume, presence or absence of IVH and blood glucose level on admission [8].

Statistical analysis of the results was carried out with the help of Statistica 13.0 software (StatSoft Inc., USA, series number JPZ804I382130ARCN10-J) and MedCalc (version 16.4). The studied traits were passed the Shapiro-Wilk test for normality. Descriptive statistics were presented in the form of mean and standard error of mean $(M \pm m)$ for values with normal distribution and in the form of median (Me) and interquartile range (Q25-Q75) for parameters with the distribution that differs from normal. Mann-Whitney test was used in order to assess the intergroup differences. The elaboration of prediction criteria was conducted with the help of binary logistic regression analysis and ROC-analysis. $P$-values of $<0.05$ were determined to represent statistical significance.

\section{Results}

Clinical sings of SSICH in the onset of the disease were characterized by a variable combination of focal neurological 


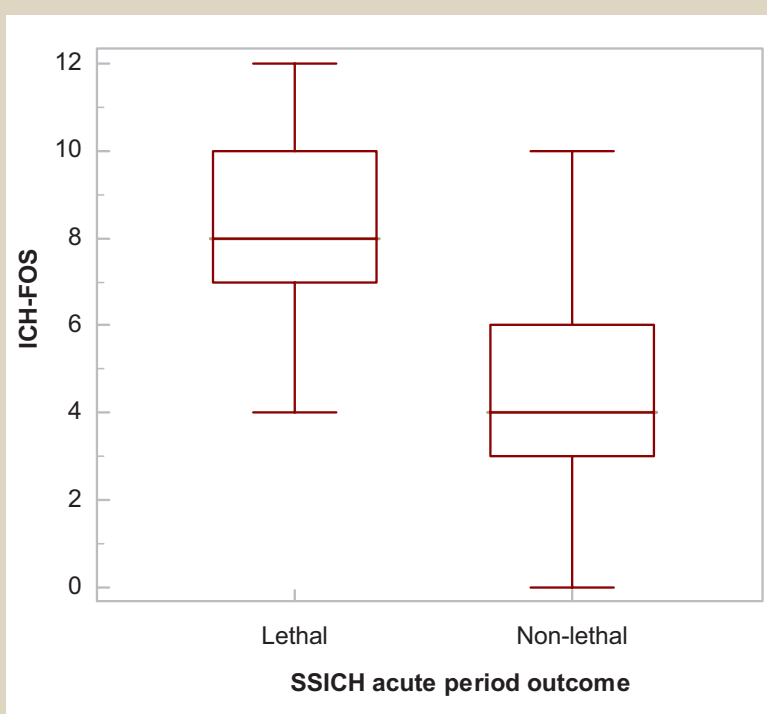

Fig. 1. ICH-FOS value in comparison with SSICH acute period outcome.

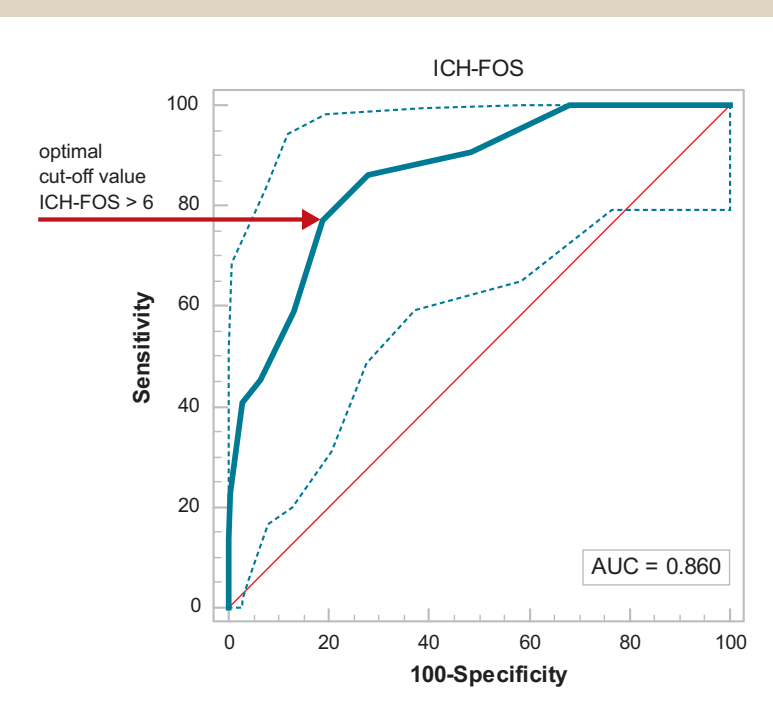

Fig. 2. Area under the curve for the assessment of the ICH-FOS informative value for the determination of a short-term vital prognosis of SSICH acute period outcome.
Table 1. The mortality rate within subgroups of patients with the different $\mathrm{ICH}-\mathrm{FOS}$ values

\begin{tabular}{|c|c|c|}
\hline ICH-FOS value & $\mathbf{N}(\%)$ & Mortality rate (\%) \\
\hline 0 & $6(3.1 \%)$ & 0.0 \\
\hline 1 & $13(6.8 \%)$ & 0.0 \\
\hline 2 & $12(6.3 \%)$ & 0.0 \\
\hline 3 & $23(12.0 \%)$ & 0.0 \\
\hline 4 & $35(18.3 \%)$ & 5.7 \\
\hline 5 & $36(18.8 \%)$ & 2.8 \\
\hline 6 & $17(8.9 \%)$ & 11.8 \\
\hline 7 & $14(7.3 \%)$ & 28.6 \\
\hline 8 & $14(7.3 \%)$ & 21.4 \\
\hline 9 & $7(3.7 \%)$ & 14.3 \\
\hline 10 & $8(4.2 \%)$ & 50.0 \\
\hline 11 & $3(1.6 \%)$ & 66.7 \\
\hline 12 & $3(1.6 \%)$ & 100.0 \\
\hline
\end{tabular}

Table 2. Results of the patients assessment in accordance with the ICH-FOS subtests results in comparison with the vital outcome of $\mathrm{SSICH}$ in the acute period, $\operatorname{Me}\left(Q_{25}-Q_{75}\right)$

\begin{tabular}{l|l|l|l|} 
Parameters, units & $\begin{array}{l}\text { Lethal outcome } \\
(\mathrm{n}=\mathbf{2 2})\end{array}$ & $\begin{array}{l}\text { Non-lethal outcome } \\
(\mathrm{n}=\mathbf{1 6 9})\end{array}$ & $\mathbf{P}$ \\
\hline Age, years & $62(52-75)$ & $66(58-75)$ & 0.3164 \\
\hline NIHSS score & $21(15-28)$ & $10(6-14)$ & $<0.0001$ \\
\hline GCS score & $10(5-13)$ & $15(14-15)$ & $<0.0001$ \\
\hline ICHV, mL & $55.5(25.1-76.5)$ & $10.5(4.6-20.9)$ & $<0.0001$ \\
\hline Blood glucose level, mmol/L & $6.9(6.0-8.0)$ & $5.6(4.9-6.5)$ & 0.0052 \\
\hline
\end{tabular}

deficit (NIHSS score $=11.3 \pm 0.4$ ) and wakefulness deficiency (GCS score $=13.2 \pm 0.2$ ), which were caused by focal lesions of supratentorial structures $(\mathrm{ICHV}=19.9 \pm 1.7 \mathrm{~mL}$ ) and by its impact on the median structures of the brain (septum pellucidum displacement $=2.7 \pm 0.3 \mathrm{~mm}$, pineal gland displacement $=2.2 \pm 0.2 \mathrm{~mm}$ ). Intraventricular hemorrhage was verified in $125(65.4 \%)$ patients.

Blood glucose level in examined cohort was $6.2 \pm 0.1 \mathrm{mmol} / /$. A stress hyperglycemia was revealed in
$46(24.1 \%)$ patients. Glycemia was considered as stress in case of whole-blood glucose level exceeding $7.0 \mathrm{mmol} / \mathrm{l}$ at the time of hospitalization, returning to normal during 72 hours and not exceeding $5.5 \mathrm{mmol} / / \mathrm{l}$ [2].

The ICH-FOS value in the studied cohort was $5.0 \pm 0.2$.

Lethal outcome was noted in 22 patients (11.5\%), unfavorable functional outcome in the form of the $\mathrm{mRS}$ score $\geq 3$ on the 21 st day of the disease was noted in 74 patients (38.7\%).

The stratification of patients based on the ICH-FOS value in comparison with the death rate in the acute period of the disease is shown in Table 1.

Table 2 shows the comparative analysis results of patients in accordance with the ICH-FOS subtests results in comparison with vital outcome in the acute period.

As shown in Table 2, patients had different values of the following indexes: NIHSS score, GCS score, ICHV and blood glucose level. The frequency of IVH and stress hyperglycemia was significantly higher in the group of patients with the lethal outcome of SSICH in the acute period $(86.3 \%$ versus $62.7 \%, X^{2}=146.5, P<0.0001$ and $50.0 \%$ versus $20.7 \%, X^{2}=187.7, P<0.0001$, respectively).

It was determined that patients with the lethal outcome in the acute period had a higher value of the ICH-FOS (8 (7-10) versus 4 (3-6), $\mathrm{P}<0.0001$ ) in the onset of SSICH (Fig. 1).

Based on a ROC-analysis it was determined that the $\mathrm{ICH}-\mathrm{FOS}>6$ is the predictor of the lethal outcome of SSICH acute period $(\mathrm{Se}=77.3 \%$; $\mathrm{Sp}=81.1 \%$; $\mathrm{AUC} \pm \mathrm{SE}$ $(95 \% \mathrm{Cl})=0.86 \pm 0.04(0.80-0.91), \mathrm{P}<0.0001)$ (Fig. 2).

In the group of patients with the ICH-FOS value $>6$ ( $n=49$ ) lethal outcome was noted in $34.7 \%$ of cases, whereas in the group of patients with the $\mathrm{ICH}-\mathrm{FOS}$ value $\leq 6$ $(n=142)$ it was noted only in $3.5 \%$ of cases. Thus, the ICHFOS value $>6$ is associated with a 9.9-fold increased risk of the lethal outcome of SSICH acute period (relative risk $95 \%$ confidence interval 3.8-25.3, $P<0.0001$ ). The accuracy of the short-term vital prognosis determination using the $\mathrm{ICH}$ FOS in the studied cohort was $90.6 \%$. 
The area under the curve value was determined for the informative value assessment of the ICH-FOS within the determination of a short-term functional prognosis of SSICH acute period outcome (AUC \pm SE $(95 \%$ $\mathrm{Cl})=0.67 \pm 0.04(0.60-0.74), \mathrm{P}=<0.0001)$. Furthermore, a comparative ROC-analysis showed that the ICH-FOS has a higher informative value for the determination of a short-term vital prognosis than for a short-term functional prognosis of SSICH acute period outcome $(P=0.0008)$.

\section{Discussion}

Thus, the study has determined that the $\mathrm{ICH}-\mathrm{FOS}$ is a highly informative tool for a short-term vital prognosis assessment in patients with $\mathrm{SSICH}$ in the onset of the disease. It is characterized by the prediction accuracy of $90.6 \%$ and AUC \pm SE $(95 \%$ Cl) $0.86 \pm 0.04$ (0.80-0.91), P < 0.0001 , which corresponds to the gradation "very good" in accordance with the international expert scale for the assessment of binary classifiers by M. H. Zweig, G. Campbell (1993) [15].

A high diagnostic informative value of the ICH-FOS has been revealed for the short-term vital prognosis determination in patients with $\mathrm{SSICH}$. In our opinion, it is due to the cumulation of the prognostic value of the ICH-FOS indexes. Herewith it has been found that patients with a lethal outcome of the acute period in the onset of $\mathrm{SSICH}$ had a higher the $\mathrm{ICH}-\mathrm{FOS}$ value, whereas intergroup differences were noted within the following ICH-FOS subtests: NIHSS score, GCS score, ICHV, presence/absence of IVH and blood glucose level.

The obtained data are consistent with the results of other studies which have proved that the initial level of neurological deficit, the cerebral syndrome severity $[6,9,13]$, $\mathrm{ICH}$ volume [10-12] and the secondary IVH presence [14] influence had been revealed as determining factors for the vital prognosis. Detected increased blood glucose level in patients with unfavourable outcome is consistent with the study of S. V. Rogoza (2015) [2], who has claimed the connection between stress hyperglycemia and the worst SSICH outcome.

During the study, it was found that the ICH-FOS $>6$ stands for a cut-off value with an optimum sensitivity $(77.3 \%)$ and specificity $(81.1 \%)$ ratio for the determination of a short-term vital prognosis. It has been proved that the ICH-FOS $>6$ is associated with a 9.9-fold increased risk of the lethal outcome of SSICH acute period. However, the ICH-FOS is less informative for the determination of a short-term functional prognosis of SSICH acute period outcome $(P=0.0008)$.

The results of the study justify the advisability to apply the ICH-FOS in order to assess the risk of a lethal outcome of SSICH acute period in the onset of the disease in order to optimize a differentiated approach as for the choice of tactics for the management of such patients.

\section{Conclusions}

1. The Intracerebral Hemorrhage Functional Outcome Score is a highly informative tool for the determination of a short-term vital prognosis of SSICH acute period outcome $(A U C \pm S E(95 \% \mathrm{Cl})=0.86 \pm 0.04(0.80-0.91), \mathrm{P}<0.0001$; prediction accuracy $-90.6 \%)$.
2. The Intracerebral Hemorrhage Functional Outcome Score $>6$ is associated with a 9.9-fold increased risk of the lethal outcome (RR $95 \%$ Cl 3.8-25.3, P<0.0001) and is the criterion for an unfavourable vital prognosis of $\mathrm{SSICH}$ acute period outcome $(\mathrm{Se}=77.3 \%$; $\mathrm{Sp}=81.1 \%$ ).

The perspective for the further scientific research is the elaboration of early neurological deterioration predictive criteria in patients with $\mathrm{SSICH}$.

Funding

The study is funded as a part of scientific research work at Zaporizhzhia State Medical University "Optimization of the diagnostic, treatment and rehabilitation approaches in patients with acute and chronic cerebral bloodflow violations", number of state registration 0113 U000798 (2013-2017).

Conflicts of interest: author has no conflict of interest to declare. Конфлікт інтересів: віАсутній.

Information about author:

Kuznietsov A. A., MD, PhD, Associate Professor of the Department of Nervous Diseases, Zaporizhzhia State Medical University, Ukraine.

Відомості про автора:

Кузнєцов А. А., канА. меА. наук, Аоцент каф. нервових хвороб, Запорізький Аержавний меАичний університет, Україна.

Сведения об авторе:

Кузнецов А. А., канА. меА. наук, Аоцент каф. нервных болезней, Запорожский госуАарственный медицинский университет, Украина.

Надійшла Ао редакції / Received: 07.09.2018

Після Аоопрацювання / Revised: 18.09.2018

Прийнято Ао Аруку / Accepted: 26.09.2018

References

[1] Ministerstvo okhorony zdorovia Ukrainy (2014). Unifikovanyi klinichnyi protokol ekstrenoi, pervynnoi, vtorynnoi (spetsializovanoi), tretynnoi (vysokospetsializovanoi) medychnoi dopomohy ta medychnoi reabilitatsii «Hemorahichnyi insult (vnutrishnomozkova hematoma, anevryzmalnyi subarakhnoidalnyi krovovylyv)». Retrieved from http://moz.gov.ua/docfiles/dod275_ukp_2014.pdf [in Ukrainian].

[2] Rogoza, S. V. (2015). Prohnozuvannia perebihu ta naslidku hostroho periodu supratentorialnoho vnutrishnomozkovoho krovovylyvu na tli arterialnoi hipertenzii [Prediction of course and functional outcome of an acute period of hypertensive supratentorial intracerebral hemorrhages against the background of arterial hypertension]. Ukrainskyi nevrolohichnyi zhurnal, 4, 49-54. [in Ukrainian].

[3] Aiyagari, V. (2015). The clinical management of acute intracerebral hemorrhage. Expert Rev Neurother, 15(12), 1421-1432. doi: 10.1586/14737175.2015.1113876.

[4] An, S. J., Kim, T. J., \& Yoon, B. W. (2017). Epidemiology, Risk Factors and Clinical Features of Intracerebral Hemorrhage: An Update. J Stroke, 19(1), 3-10. doi: 10.5853/jos.2016.00864.

[5] Cai, X., \& Rosand, J. (2015). The Evaluation and Management of Adult Intracerebral Hemorrhage. Semin Neurol, 35(6), 638-645. doi: 10.1055/s-0035-1564687.

[6] Finocchi, C., Balestrino, M., Malfatto, L., Mancardi, G., Serrati, C., \& Gandolfo, C. (2018). National Institutes of Health Stroke Scale in patients with primary intracerebral hemorrhage. Neurol Sci. doi: 10.1007/ s10072-018-3495-y.

[7] Hung, L. C., Sung, S. F., Hsieh, C. Y., Hu, Y. H., Lin, H. J., Chen, Y. W. et al. (2017) Validation of a novel claims-based stroke severity index in patients with intracerebral hemorrhage. J Epidemiol, 27(1), 24-29. doi: 10.1016/j.je.2016.08.003.

[8] Ji, R., Shen, H., Pan, Y., Wang, P., Liu, G., Wang, Y., et al. (2013). A novel risk score to predict 1 -year functional outcome after intracerebral hemorrhage and comparison with existing scores. Crit Care, 17(6), R275. doi: $10.1186 / \mathrm{cc} 13130$ 
[9] Mattishent, K., Kwok, C. S., Ashkir, L., Pelpola, K., Myint, P. K., \& Loke, Y. K. (2015). Prognostic Tools for Early Mortality in Hemorrhagic Stroke: Systematic Review and Meta-Analysis. J Clin Neurol, 11(4), 339-48. doi: 10.3988/jcn.2015.11.4.339.

[10] Rahmani, F., Rikhtegar, R, Ala, A., Farkhad-Rasooli, A., \& Ebrahimi-Bakhtavar, H. (2018). Predicting 30-day mortality in patients with primary intracerebral hemorrhage: Evaluation of the value of intracerebral hemorrhage and modified new intracerebral hemorrhage scores. Iran J Neurol, 17(1), 47-52.

[11] Safatli, D. A., Günther, A., Schlattmann, P., Schwarz, F., Kalff, R. \& Ewald, C. (2016). Predictors of 30-day mortality in patients with spontaneous primary intracerebral hemorrhage. Surg Neurol Int, 7(18), 510-517. doi: 10.4103/2152-7806.187493.

[12] Spina, S., Marzorati, C., Vargiolu, A., Magni, F., Riva, M., Rota, M., et al. (2018). Intracerebral hemorrhage in intensive care unit: early prognostication fallacies. A single center retrospective study. Minerva Anestesiol., 84(5), 572-581. doi: 10.23736/S0375-9393.17.12225-X.

[13] Sung, S. F., Hsieh, C. Y., Lin, H. J., Chen, Y. W., Chen, C. H., Kao Yang, Y. H., \& Hu, Y. H. (2016). Validity of a stroke severity index for administrative claims data research: a retrospective cohort study. BMC Health Serv Res, 16(1), 509. doi: [10.1186/s12913-016-1769-8].

[14] Yuan, R., Lei, C., Wu, S., Wei, C., Xiong, Y., Xu, M., et al. (2017). Prognostic Significance of Intraventricular Hemorrhage in Vascular Structural Abnormality-Related Intracerebral Hemorrhage. J Stroke Cerebrovasc Dis, 26(3), 636-643. doi: 10.1016/j.jstrokecerebrovasdis.2016.11.012.

[15] Zweig, M. H., \& Campbell, G. (1993). Receiver-operating characteristic (ROC) plots: a fundamental evaluation tool in clinical medicine. Clin Chem, 39(4), 561-577. 